\title{
Autopsy Evaluation of Defence Wounds in Homicidal Death in Central India
}

\author{
Prakash M Mohite ${ }^{1}$, Deepali P Mohite ${ }^{2}$, Pradeep G Dixit ${ }^{3}$, Anil J Anjankar ${ }^{1}$ and Atul S Keche ${ }^{1}$
}

${ }^{1}$ Department of Forensic Medicine \& Toxicology, Jawaharlal Nehru Medical College, Sawangi (M), Wardha, Maharashtra, India ${ }^{2}$ Department of Oral Pathology \& Microbiology, SDKSD College \& Hospital, Hingna, Nagpur, Maharashtra, India ${ }^{3}$ Department of Forensic Medicine \& Toxicology, Govt. Medical College \& Hospital, Nagpur, Maharashtra, India

\begin{abstract}
Defence wounds are injuries which are suffered by an individual in an attempt to save oneself from assault or while defending oneself from the offenders. The nature of these wounds varies depending on the type of weapon used, amount of force and the state of consciousness at the time of attack. They are of great significance in differentiating between manner i.e. homicide, suicide and accident. Hence the present study was undertaken to differentiate the pattern of injuries during defence in Homicidal deaths. A total of 205 cases of homicide were studied. Defence wounds were present in $44.4 \%$ of cases, out of which $92.3 \%$ were male and $7.7 \%$ cases were females. Maximum number of cases (45.1\%) with defence wounds belonged to age group 20-29 years. Defence wounds present in injuries caused by sharp cutting weapon with stab wound were less (36.55) as compared to hard and blunt object $(57.1 \%)$. In $30.8 \%$ cases defence wounds were present in more than one part of body. In $17.6 \%$ of cases alcohol was found in the contents of the stomach on post-mortem examination. Conclusion: The occurrence of defence wounds varies according to social, political, economic and cultural conditions of the area. The region of Central India is an agricultural region where use of sharp instruments is more common. The institute where this study was conducted is a cultural capital where fights between various social groups take place frequently.
\end{abstract}

Keywords: Causative object; Defence wound; Homicidal death; Stab wound

\section{Introduction}

A wound can be broadly defined as a "disruption of the continuity of tissues produced by external mechanical force". (From the old English wund and the Old Norse und). Wounds which are present over the body to defend oneself from an assault are called defence wounds. They result due to the immediate and instinctive reaction of the victim to save oneself either by raising the body part to prevent the attack or by grasping the weapon used in attack. Presence of defence wound implies that the victim was able to put some resistance to an assault, at some stage during that assault [1].

Defence wounds are of great significance in differentiating manner of unnatural deaths i.e. Homicide, Suicide and Accident. In an assault, the natural reaction of the victim is to protect oneself and certain vital parts of the body like eyes, face, chest and head. Forearms, hands, elbows and legs are raised instinctively; hence defence wounds are more common on these parts of body. Defence wound depends on suddenness of assault and other factors like type of weapon used, Nature of wound, Intoxication, Position of assailant and victim. Presence of defence wounds indicate that victim was conscious, partly mobile and was not taken completely by surprise or was not taken unawares. Absence of defence wounds in few cases of homicides does not mean that defensive activity did not take place and hence does not rule out the possibility of homicide [2]. Metter and Benz (1989) [3] study found defence injuries in 48\% of Homicidal cases. Karlsson (1998) [4] in his study identified defensive injuries in $41 \%$ of homicide victims, but not at all in suicides. Katkici et al found defence injury in $38.5 \%$ of cases [2]. Schmidt and Pollak [5] found in 45.9\% of cases in his study [5].

Various studies show that the prevalence, location and effective factors associated with defence wounds vary worldwide and can be an indication of the country and the region where they would have taken place [2]. Evaluation of defence wound in cases of homicide was carried out in the Tertiary centre hospital in the region of Central India with following aims and objectives:

\section{Aims and objectives}

1) To determine predominance of defence injury.

2) To determine the part of body most commonly involved in defence.

3) To determine effective factors responsible for defence wound.

4) To determine role of alcohol.

5) o determine active and passive defence wound. Active means the victim tried to grab the weapon and the wounds are on the palmer surfaces and between fingers of the hand. Passive means that the wounds are on the dorsal surface of the hand or forearm or leg due to natural reaction of the victim.

\section{Materials and Methods}

The present study was carried out in the Department of Forensic Medicine and Toxicology at Government Medical College and Hospital, Nagpur over a period of 3 years From Jan 2003 to Dec 2006

*Corresponding author: Prakash M Mohite, Department of Forensic Medicine \& Toxicology, Jawaharlal Nehru Medical College, Sawangi (M), Wardha-442 004, Maharashtra, India, Tel: 091-9850397120/091-8149086478; E-mail: drprakashmohite@rediffmail.com

Received October 21, 2013; Accepted November 18, 2013; Published November 21,2013

Citation: Mohite PM, Mohite DP, Dixit PG, Anjankar AJ, Keche AS (2013) Autopsy Evaluation of Defence Wounds in Homicidal Death in Central India. J Forensic Res 4: 205. doi:10.4172/2157-7145.1000205

Copyright: (c) 2013 Mohite PM, et al. This is an open-access article distributed under the terms of the Creative Commons Attribution License, which permits unrestricted use, distribution, and reproduction in any medium, provided the original author and source are credited. 
Page 2 of 4

A cross-sectional retrospective study was carried out with all cases of homicides except those caused by strangulation, burns and firearms were included in the study. Complete post-mortem examination with detailed description of injuries was done. The study sample was divided into six groups, each group comprising of a decade (Table 1).

\section{Results and Observations}

Evaluation of defence wounds in all the cases showed a male predominance in the region of Central India as shown in Table 2. A higher incidence of defence wounds occurred in the age group 20-39 years (65/121, i.e., in $53.7 \%$ cases) than at the extremes of the ages as shown in Table 3. Table 4 demonstrates an overall $60.29 \%(44 / 73)$ cases show defence wound in deaths due to stab injury. Defence wounds were normally seen in victims of homicides where number of assaulted injuries was more than 4 with either type of weapon as evident from Tables 5 and 6. There was a higher incidence of defence wounds in cases of assault with sharp cutting object as compared to hard and blunt object as can be inferred from Tables 7 and 8 . Out of the total cases showing defence wounds in $22 \%$ cases injuries were on the forearm with equal distribution on both sides. Next common site was arm (19.8\%) cases with more injuries on left side where as injuries on palmer and dorsal aspect of hand was seen in $9.9 \%$ and $12.1 \%$ cases respectively. overall in $37.4 \%$ of cases injuries were seen on left side where as in $24.2 \%$ of cases it was on right side as shown in Table 9 . This is because of right handed accused assaulting from the front. In $38.54 \%$ of cases wounds were seen on both sides of the body. Site of defence

\begin{tabular}{|c|c|}
\hline Age $(\mathbf{y r s})$ & Total no of cases \\
\hline $10-19$ & 14 \\
\hline $20-29$ & 63 \\
\hline $30-39$ & 58 \\
\hline $40-49$ & 39 \\
\hline $50-59$ & 19 \\
\hline$\geq 60$ & 12 \\
\hline Total & 205 \\
\hline
\end{tabular}

Table 1: A cross-sectional retrospective study between age vs. no. of cases.

\begin{tabular}{|l|l|l|l|}
\hline Sex & Wound present & Wound absent & Total (\%) \\
\hline Male & 84 & 94 & $178(86.8 \%)$ \\
\hline Female & 07 & 20 & $27(13.2 \%)$ \\
\hline Total & $91(44.4 \%)$ & $114(65.6 \%)$ & 205 \\
\hline
\end{tabular}

In the present study $86.8 \%$ cases were males and $13.2 \%$ females. In males (84/178) $47.2 \%$ showed presence of defence wounds while in females (07/27) $25.9 \%$ showed defence wound. In all defence wound was present in $44.4 \%$ cases.

Table 2: Sex distribution of homicidal victims with defence wounds.

\begin{tabular}{|l|c|c|c|}
\hline Age (yrs) & Present & Absent & Total \\
\hline $10-19$ & 2 & 12 & 14 \\
\hline $20-29$ & 41 & 22 & 63 \\
\hline $30-39$ & 24 & 34 & 58 \\
\hline $40-49$ & 12 & 27 & 39 \\
\hline $50-59$ & 10 & 09 & 19 \\
\hline$\geq 60$ & 02 & 10 & 12 \\
\hline Total & 91 & 114 & 205 \\
\hline
\end{tabular}

Of all the studied cases none was below 10 years of age. Incidence of homicidal deaths were most in the age group of $20-29$ years, i.e., $63 / 205(30.7 \%)$ while less incidence was seen in cases above 60 years of age 12/205 (5.9\%). Defence wounds were present in large number in $41 / 63(45.1 \%)$ cases in the age group 20-29 years followed by age group $30-39$ years with $24 / 58(41.4 \%)$ cases showing defence wounds. Thus higher incidence of defence wounds occurred in $53.7 \%$ cases in the age group 20-39 years $(65 / 121)$ than at the extremes of the ages.

Table 3: Defence wounds seen in different age group.

\begin{tabular}{|l|c|c|c|}
\hline No. of Stab wound & Present & Absent & Total \\
\hline 01 & 03 & 05 & 08 \\
\hline 02 & 02 & 08 & 10 \\
\hline 3 to 9 & 12 & 07 & 19 \\
\hline$\geq 10$ & 27 & 09 & 36 \\
\hline Total & 44 & 29 & 73 \\
\hline
\end{tabular}

Of the 205 Homicidal deaths studied, stab wounds were present in only 73 (35.6\%) cases, of which higher incidence of defence wound was seen in $75 \%$ of cases with $\geq 10$ stab wound $(27 / 36)$. Overall $60.29 \%$ (44/73) cases show defence wound in deaths due to stab injury.

Table 4: Defence wound in correlation to death caused by (Stab wounds) sharp cutting object and the number of wounds inflicted.

\begin{tabular}{|l|l|l|l|}
\hline No. of wounds & Present & Absent & Total \\
\hline $2-4$ & $\begin{array}{l}3(7.7 \%) \\
(7 \%)\end{array}$ & $\begin{array}{l}40(51.3 \%) \\
(93 \%)\end{array}$ & $43(36.7 \%)$ \\
\hline More than 4 & $\begin{array}{l}36(92.3 \%) \\
(48.6 \%)\end{array}$ & $\begin{array}{l}38(48.7 \%) \\
(51.4 \%)\end{array}$ & $74(63.2 \%)$ \\
\hline Total & $39(33.3 \%)$ & $78(66.7 \%)$ & 117 \\
\hline
\end{tabular}

Of the 205 Homicidal deaths studied, 117 cases were deaths due to assault by hard and blunt object. Overall Defence wound was seen in $33.3 \%(39 / 117)$ cases. While defence wounds were more in cases showing $>4$ injuries on assault, i.e. $48.6 \%(36 / 74)$.

Table 5: Correlation of defence wounds present in death caused by hard and blunt objects.

\begin{tabular}{|l|l|l|l|}
\hline No. of wounds & Present & Absent & Total \\
\hline$\geq 4$ & 8 & 7 & 15 \\
\hline
\end{tabular}

15 cases $7.3 \%$ (15/205) showed injuries caused by both hard and blunt and sharp cutting objects. Defence wound with $\geq 4$ injuries was seen in $53.3 \%(8 / 15)$ cases.

Table 6: Correlation of Defence wound in cases of death caused by both sharp cutting and Hard and Blunt object.

\begin{tabular}{|l|l|l|l|}
\hline $\begin{array}{l}\text { Type of object } \\
\text { used }\end{array}$ & $\begin{array}{l}\text { Defence wound } \\
\text { present }\end{array}$ & $\begin{array}{l}\text { Defence wound } \\
\text { absent }\end{array}$ & Total \\
\hline Sharp cutting & 44 & 29 & 73 \\
\hline Hard and Blunt & 39 & 78 & 117 \\
\hline Both & 08 & 07 & 15 \\
\hline Total & 91 & 114 & 205 \\
\hline
\end{tabular}

A total of (91/205) $44.39 \%$ cases showed defence injuries during assault. Most number of wounds was present when sharp cutting weapon was used for assault. Absence of defence wounds was more noted more in cases when hard and blunt object was used for assault.

Table 7: Correlation of defence wound present in Homicidal deaths caused by using various type of objects.

\begin{tabular}{|l|l|l|l|l|l|}
\hline \multicolumn{3}{|l|}{ Cases with defence wounds } & \multicolumn{3}{|l|}{ Cases without defence wounds } \\
\hline $\begin{array}{l}\text { Smell } \\
\text { present }\end{array}$ & $\begin{array}{l}\text { Smell } \\
\text { absent }\end{array}$ & Total & $\begin{array}{l}\text { Smell } \\
\text { present }\end{array}$ & $\begin{array}{l}\text { Smell } \\
\text { absent }\end{array}$ & Total \\
\hline $16(17.6 \%)$ & $75(82.4 \%)$ & $91(44.4 \%)$ & $30(26.3 \%)$ & $84(73.7 \%)$ & $114(55.6 \%)$ \\
\hline
\end{tabular}

Out of 205 cases, defence wound was seen in 91 (44.4\%) cases, while 114 cases do not show any signs of defence wound. In $82.4 \%$ cases with defence wound alcohol had not been consumed. In $26.3 \%$ cases without defence wound, alcohol had been consumed.

Table 8: Correlation of Defence wounds and smell of alcohol to gastric contents.

wounds may depend on Right handed or left handed offender and also the direction from which the victim was attacked, i.e. from front, back or on either side of the body the injuries were inflicted. Wounds seen on the dorsal aspect were passive defence wounds depicting the natural reaction of the victim to defend or protect the blow on the vital part of the body when taken by surprise. Wounds on the palmer aspect of hand are suggestive of active defence wounds found in a young alert and conscious victim who got a chance to defend thus suffering more than one injury. 


\begin{tabular}{|l|l|l|l|l|}
\hline Location & Present & \multicolumn{3}{l|}{ Present } \\
\cline { 2 - 4 } & Left & Right & Both & \\
\hline $\begin{array}{l}\text { Palmer surface of } \\
\text { hand }\end{array}$ & $\begin{array}{l}6(17.6 \%) \\
(66.6 \%)\end{array}$ & $\begin{array}{l}1(4.5 \%) \\
(11.1 \%)\end{array}$ & $\begin{array}{l}2(5.7 \%) \\
(22.2 \%)\end{array}$ & $09(9.9 \%)$ \\
\hline $\begin{array}{l}\text { Dorsal surface of } \\
\text { hand }\end{array}$ & $\begin{array}{l}7(20.6 \%) \\
(63.6 \%)\end{array}$ & $\begin{array}{l}4(18.2 \%) \\
(36.4 \%)\end{array}$ & 0 & $11(12.1 \%)$ \\
\hline Forearm & $\begin{array}{l}8(23.5 \%) \\
(40 \%)\end{array}$ & $\begin{array}{l}8(36.4 \%) \\
(40 \%)\end{array}$ & $\begin{array}{l}4(11.4 \%) \\
(20 \%)\end{array}$ & $20(22 \%)$ \\
\hline Arm & $\begin{array}{l}10(29.4 \%) \\
(55.6 \%)\end{array}$ & $\begin{array}{l}7(31.8 \%) \\
(38.9 \%)\end{array}$ & $\begin{array}{l}1(2.9 \%) \\
(5.6 \%)\end{array}$ & $18(19.8 \%)$ \\
\hline Any other part & $\begin{array}{l}3(8.8 \%) \\
(60 \%)\end{array}$ & $\begin{array}{l}2(9.1 \%) \\
(40 \%)\end{array}$ & 0 & $05(5.5 \%)$ \\
\hline Combined & - & - & $\begin{array}{l}28(80 \%) \\
(100 \%)\end{array}$ & $28(30.8 \%)$ \\
\hline Total & $34(37.4 \%)$ & $22(24.2 \%)$ & $35(38.54 \%)$ & 91 \\
\hline
\end{tabular}

Out of the total cases showing defence wounds in $22 \%$ cases injuries were on the forearm with equal distribution on both sides. Next common site was arm (19.8\%) cases with more injuries on left side where as injuries on palmer and dorsal aspect of hand was seen in $9.9 \%$ and $12.1 \%$ cases respectively. overall in $37.4 \%$ of cases injuries were seen on left side where as in $24.2 \%$ of cases it was on right side. This is because of right handed accused assaulting from the front. In $38.54 \%$ of cases wounds were seen on both sides of the body.

Table 9: Correlation of defence wounds and their location.

\section{Discussion}

Homicide is one of the leading causes of death worldwide and head is the target in majority of cases [6]. The presence of defensive or violence associated traumatic wounds is indicative of a homicide [7]. The presence of defence wounds help in differentiating between homicide, suicide and accidental deaths [2].These wounds are mainly seen on the upper limbs because these are the body parts with which a defendant raises to save himself. The left side of the victim is commonly involved as this is nearest to the accused person with the preponderance of right handed individuals in the society [8]. Presence of 'Defensive wounds' implies that the victim was able to put up some resistance to an assault, at some stage during that assault [6]. Presence of defence wound if any also proves that the given case is of homicide; as it is a natural reaction of an individual to defend oneself at the time of assault. The present study was aimed to evaluate defence wound present in Homicidal deaths caused by the use of various types of weapon like Sharp cutting or Hard and Blunt objects or by both type of objects. In this study, incidence of defence wounds in homicidal attacks was seen in $44.4 \%$ of cases which is similar to studies carried out by U. Katkici et al. [2] (38.5\%), Camps et al. [9], Mohanty et al. [8] (33.3\%), Karlsson [4] (41\%).

Males were the predominant group showing defence wounds ( $92.3 \%$ cases) in our study which is due to male dominant society in this region. Secondly being an agricultural region; Land disputes between the family members and conflict between various antisocial groups where males are the members hence predominance of male victims in homicide is observed which is similar to Gupta Avneesh et al. [10] who found three times more incidence of defence wounds in males than in females and is also similar to the study of Mohanty et al. [8] Showing male preponderance with $85.2 \%$ of cases showing defence wounds. Shotar and Jaradat [11] found defence wounds in $79.3 \%$ of males and $20.69 \%$ of female cases where as Hugar BS et al found $72.5 \%$ were males and $27.5 \%$ were females [12] as against $35.2 \%$ by Katkici et al. [2], Hunt and Cowling [13]. It may be due to more violence on women in the region of their study. Schimdt et al. [5] did not find any significant difference between males and females. This increase in percentage of defence wounds in males indicates that they show more aggressive behaviour turning to violence as compared to females. Amongst males the age group between 20-39 years consisted of the most number of cases with defence wounds (53.1\%) demonstrating similarity with the study carried out by Katkici et al. [2], Gupta et al. [10] (38\%), Mohanty et al. [14] (38\%), Ali M Shotar et al. [11], Hugar et al. [12] (46-79.3\%) of cases below 30 years of age group. Lowest involved group was of persons more than 60 years of age and victims below the age of 19 years. It may be due to weaker section of the society who is unaware of the assault or sudden attack or known relative being the offender, so they don't suspect any foul play.

The presence of defence wounds in younger age group indicates a better reaction to sudden assault. Individuals of this age group are more alert and respond quickly and spontaneously to sudden attack. As age advances the response to sudden attacks weakens and individuals show relatively fewer defence wounds.

Defence wounds were present in $60.3 \%$ cases of stab injuries whereas it was $33.3 \%$ in cases showing injuries caused by hard and blunt objects. Defence wound was commonly seen in individuals/victims showing more number of injuries as compared to victim showing a single wound, which proves that more the number of injuries more are the chances of defence wounds, suggesting that the victim gets a greater chance to defend himself as was observed by Mohanty et al. [14].

Alcohol consumed by the victim around the time of attack weakens the activity of defence. This is evident in our study where defence wounds were present in only $17.6 \%$ cases in which there was smell of alcohol to the gastric contents as compared to $82.3 \%$ cases where victims had not consumed alcohol similar to study by Katkici et al. [2] According to Katkici et al. [2], alcohol is a resistance breaking factor.

The present study shows presence of defence wounds predominantly on the arm, forearm and dorsal surface of the hand. Defence wounds obtained whilst fending off an assailant with a knife are typically found on the dorsum of the hand and backs of the forearms (ulnar border) and upper arms. When an attempt is made to grab the knife blade from the assailant, incised wounds may be found between the thumb and fingers, across the palms or in the webspace between the bases of the thumb/ index finger. Next in the order of occurrence was palmer surface of the hand and other parts like back of the shoulder. In 38.5\% cases defence wounds were present on both sides whereas it was present on left side in $37.4 \%$ cases and on right side in $24.2 \%$ cases. Similar findings were noted in a study carried out by Knight [1], Katkici et al. [2], Metter and Benz [3], Camps et al. [9], Hugar et al. [12], Curran et al. [15]. This is because of prevalence of right handed persons in the society.

Depending upon the type of weapon producing the most number of defence wounds, we concluded that assault by sharp cutting weapon produced more defence wounds as compared to assault with hard and blunt objects similar findings were noted by Inoue et al. [16]. Stab wounds are incised wounds where the length of injury on the surface is less than the depth of penetration into the body, and are the result of a thrusting action, where the force is delivered along the long axis of a narrow, pointed object. The force of impact is concentrated at the tip of the implement, and the sharper the tip, the easier it will penetrate the skin. The injuries caused by light weight sharp cutting, sharp and pointed or heavy sharp cutting weapons were not segregated all were included in the category of sharp cutting weapons.

\section{Summary and Conclusion}

The study was carried out to evaluate the nature of defence wounds present in victims of Homicides assaulted by different kinds of weapons. Depending on the geographical and cultural background of the area it 
Citation: Mohite PM, Mohite DP, Dixit PG, Anjankar AJ, Keche AS (2013) Autopsy Evaluation of Defence Wounds in Homicidal Death in Central India. J Forensic Res 4: 205. doi:10.4172/2157-7145.1000205

Page 4 of 4

is observed that there is male preponderance and younger age group is more commonly involved. Defence wound was obviously seen in cases where number injuries were noticed which show that conscious or alert victims tends to better defend oneself. Defence wounds were observed in cases of assault by sharp edged objects as compared to hard and blunt objects in which victims may not get a chance to defend themselves due to fatal blow. It is observed that alcohol consumption by the victim decreases the resistance factor for defence. Forearm, arm and hand are the common sites observed for the defence which is due to natural reaction of a conscious victim showing both active and passive defence wounds. $44.4 \%$ cases in the present study shows the presence of defence wounds. The absence of defence wounds in the remaining cases might have been because the victim did not have a chance to defend himself from the attack. This may be either due to a single fatal blow, suddenness of attack or the victim being taken by surprise as the offender being a close relative. The absence of defence wounds may also be due to intoxicating effect of alcohol which may hinder the response to attack. Thus absence of defence wound does not rule out the possibility of homicide but presence of defence wound in an assaulted case definitely proves of a homicidal intent.

\section{References}

1. Knight B (1991) Forensic Pathology. London Edward Arnold Ltd.

2. Katkici U, Ozkök MS, Orsal M (1994) An Autopsy evaluation of defence wounds in 195 homicidal deaths due to stabbing. J Forensic Sci Soc 34: 237-240.

3. Metter D, Benz D (1989) Self defence injuries in homicides caused by penetrating forces. Z Rechtsmed 102: 277-291.
4. Karlsson T (1998) Homicidal and suicidal sharp force fatalities in Stockholm Sweden. Orientation of entrance wounds in stabs gives information in the classification. Forensic Sci Int 93: 21-32.

5. Schmidt U, Pollak S (2006) Sharp force injuries in clinical forensic medicinefindings in victims and perpetrators. Forensic Sci Int 159: 113-118.

6. Lecture notes. Department of FM, University of Dundee.

7. Brunel C, Fermanian C, Durigon M, de la Grandmaison GL (2010) Homicidal and suicidal sharp force fatalities: Autopsy parameters in relation to the manner of death. Forensic Sci Int 198: 150-154.

8. Mohanty MK, Panigrahi MK, Mohanty S, Dash JK, Dash SK (2007) Self defence injuries in homicidal deaths. J Forensic Leg Med 14: 213-215.

9. Camps FE, Robonson AE, Lucas BGB, Thomas FC (1976) Gradwohl's Lega Medicine. (3rdedn.) Brostol; John Wright \& Sons. Ltd.

10. Gupta A, Rani M, Mittal AK, Dikshit PC (2004) A study of homicidal deaths in Delhi. Med Sci Law 44: 127-132.

11. Shotar AM, Jaradat S (2007)A Study of wound fatalities in the north of Jordan. Med Sci Law 47:239-243.

12. Hugar BS, Harish S, Girish Chandra YP, Praveen S, Jayanth SH (2012) Study of defence injuries in homicidal deaths - An autopsy study. J Forensic Leg Med 19: 207-210.

13. Hunt AC, Cowling RJ (1991) Murder by stabbing. Forensic Sci Int 52: 107-112.

14. Mohanty S, Mohanty MK, Panigrahi MK, Das SK (2005) Fatal head injury in homicidal victims. Med Sci Law 45: 244-248.

15. Curran WJ, McGarry L and Petty CS (1980) Modern Legal Medicine Psychiatry and Forensic Science, Philadelphia; FA Davis Company.

16. Inoue H, Ikeda N, Ito T, Tsuji A, Kudo K (2006) Homicidal sharp force injuries inflicted by family members or relatives. Med Sci Law 46: 135-140. 